\title{
CounterPoint:
}

\section{If Libraries Don't Change, They Won't Be the Place to Get the Books}

- David G. Fergusson

$\mathrm{H}$ aving read Tom Moore's article, I feel torn. First, I agree with a lot of what he says, so I am naturally questioning myself. Moore has been tossing his ideas around North Carolina for a generation, loving the controversy he has caused, and when we roll over and publicly agree with him without a whimper, I think he subconsciously finds it upsetting. So I won't go that far. I agree with him about his central assertion as to the permanence of the book: if the book ain't broke, don't fix it. But I generally believe that we are in an excellent position to influence the future for libraries so that they will stay in the forefront of American culture.

Let's look at a few of your assertions.

Is a book still economical? Actually books are sort of pricey, especially for those who read a lot, so I'd say they are economical if you get them at the library. And in reference to your statement that "the reading device of the future must have NO BATTERIES!" What is up with that? In case you haven't left the library in a while, people are in love with battery-driven devices today, and perhaps your kids are the exception. After talking on their batterydriven cell phones, and riding in their battery-driven hybrid cars while listening to talking books on their battery-driven MP3 players, folks now spend the day pounding away on their battery-driven laptops. One of our branch heads uses a battery-driven lawn mower. The only thing missing is battery-driven food.

No, I think the book will remain a for a long time, but as new devices now supplement books, they will someday replace them for many users. My slant on the B. F. Skinner quote, "we ought not to teach our children the great books, we ought to teach them the love of reading," is this: I hope he would consider the love of reading indicative of the love of literature, knowledge, and intellectual discovery, whatever the format or delivery system, because it won't always be books. It is cheaper for a library only to provide books, and if I only observed people reading books around town or in the library, it would make sense. But we know that is not true. Diversity of the population seems to breed diversity in access choices. We are PUBLIC libraries and this is our challenge.

How about the future of public libraries? Moore makes a few assertions I'd like to discuss, however I want to put my thoughts about how we look at the future in context. Change comes slowly where people are concerned. I was a history major in college, and today's computerized technology has changed as much as anything I recall studying. But generally I look at my life, which began in 1948, and much more change has occurred in people's minds than in their surroundings. TV arrived shortly after I did, and hasn't changed much. We now have color, and more channels, but you can only watch one thing at a time. I drive a car fundamentally very similar to those of the fifties. I get in and drive around, parking on the same streets, wearing 
very similar clothes. I eat pretty much the same food in pretty much the same type house. Social movements and the economic structure of our society have changed along with how we think about them, but again I do not notice it happening very fast! We are not caught in a social tsunami moving at breakneck speed. The change is coming, but fortunately I think the library community has time to adapt.

Moore points out that libraries are hurt by reduced funding from taxes. He recommends finding a long-term financial solution that doesn't rely on taxes alone. This makes sense as long as we maintain a tax base that will not be cut in proportion to new sources of support. His other solution is to focus on books and reading, getting "back to basics." He says we must focus on having what citizens want "when they want to read it." Here, I respectfully differ.

Many libraries have never, ever done well marketing the great products they have. A 2003 Marist College Institute of Public Opinion survey on the Public Library indicated that access to a public library in their community is rated "very valuable" by $67 \%$ of respondents and "valuable" by another $27 \%$. Sixty-three percent of the public "supports" or "strongly supports" an increase in taxes for public library services in their communities. The average tax increase they are willing to pay is $\$ 49$ per year. That's over two and a half times the average per capita support of North Carolina's public libraries. Sounds like we live and work in the land of opportunity! Libraries must finally find a way to get the people really to speak for them.

Moore states that our problem is an anti-tax movement, but the survey I just mentioned makes me wonder. We clearly face a difficult task. For years we have provided a pretty good supply of books for reading, and we need to continue to provide the traditional services you cherish. But we also need to be flexible, since we are at the behest of a shifting economy and electorate. Life changes very slowly, but tastes and wants change overnight, and we've got to meet the public's perceived need with a quality product.

One popular public library role is that of a community gathering point or "commons." While most people read at home, the visit, the moment, is the memory I have of my many trips to the library. This cannot be emphasized enough. We keep lamenting the glitter of Borders and Barnes \& Noble, all the while knowing that the income they derive keeps them going. I can't pass up the opportunity to point out that the splendid little bookstores, that these big box bookstores are alleged to have put out of business, offered great literature provided by loving staff. In fact, the big box stores added value by simply adding to the experience. We cannot be exactly the same; our goal should be "different and better." We probably should ask the people we serve, the ones who want our services and are theoretically willing to pay for them, what they really want. And we should keep changing to provide it. This is where libraries will have to learn to love change and practice it over and over. Tom correctly states that if we don't use our libraries, we will lose them.

Of course, we do use them. The central library where I work counts over 1,000 visitors a day. That means that we are the wheel! You don't have to reinvent it. We want people to realize that they should always think "library!" first. Tom, the thing people have always known is that we provide lots of free good books. It's the other services that they don't know about! This never ceases to amaze librarians because our other offerings are so wonderful and varied.

Marketing for the future also means customer service. Libraries offer customer service that ranges from great to mediocre. How often have we been told that ours is becoming a service-driven economy? No library should let its standard for customer service fall below excellent. In a service-driven economy, where service is generally not very good, ours needs to stand out. 
Flexibility is essential. It is a buzzword in our economy in general and if we think libraries can avoid facing it, we are wrong and will keep missing opportunities for positive development. It is no secret that libraries, with a relatively low level of purchasing power, are at the behest of the ever-changing consumer economy. We don't drive the economy, but we can make the most of it if we are flexible in restructuring our services to satisfy our customers.

We can keep improving the future of public libraries if people know that we will give them what they want and need in stimulating surroundings, using amiable employees to create a captivating experience. Libraries flexible enough to welcome people who keep showing up with a growing number of changing needs will thrive as well. It's a whole package, a package that is changing, and we should be loving the change! 